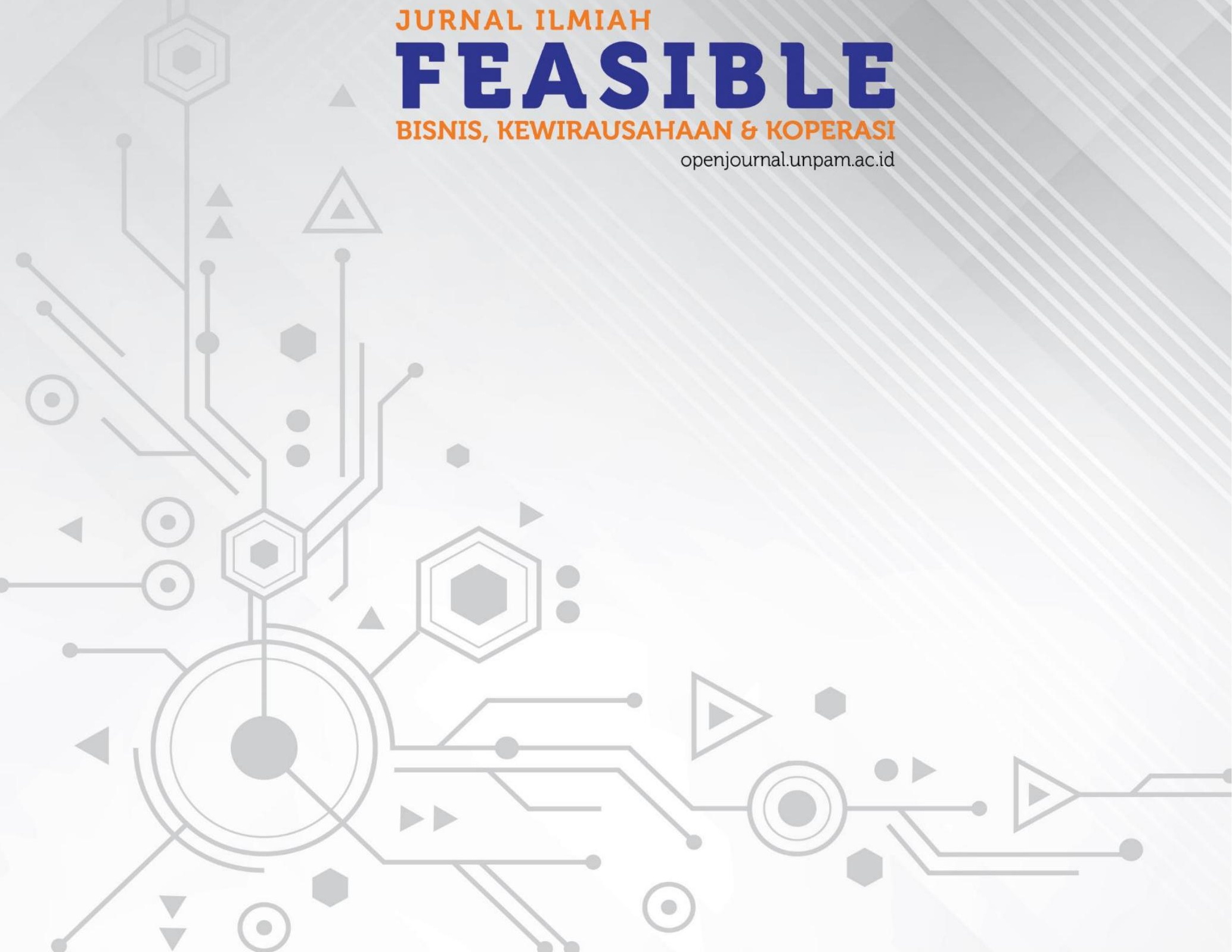


P-ISSN : 2655-9811, E-ISSN:2656-1964

J. Feasible., Vol. 2, No.2, Agustus 2020 (115-125)

0 2019 Pusat InkubasiBisnis dan Kew irausahaan

Universitas Pamulang (PINBIKUNPAM)
Juprat r rmaAh

FEASIBLE

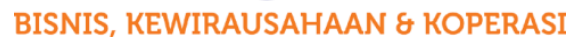

\title{
PENGARUH KUALITAS PELAYANAN TERHADAP KEPUASAAN PELANGGAN PADA PT. MEDIA TELEVISI INDONESIA (METRO TV)
}

\author{
Ugeng Budi Haryoko'); Angga Pratama); Dina Nofitriani3) \\ Prodi Manajemen, Universitas Pamulang \\ ugengbudiunpam@gmail.com
}

\begin{abstract}
Abstrak
Penelitian ini bertujuan untuk mengetahui seberapa besar Pengaruh Kualitas Pelayanan Terhadap Kepuasaan Pelanggan. Dan perusahan yang menjadi objek penelitian ini adalah PT. Media Televisi Indonesia (Metro TV). Metode penelitian yang digunakan adalah bersifat daskriptif Assosiatif dengan pendekatan kuantitatif. Populasi dalam penelitian ini adalah pelanggan pada PT. Media Televisi Indonesia (Metro TV). Dengan menggunakan sampel tidak jenuh sebanyak 96 responden. Teknik pengumpulan data dengan cara kuesioner, dan teknik analisis data adalah uji validitas, uji reliabilitas, analisis regresi linear sederhana, analisis koefisien korelasi, koefisien determinasi, dan pengujian hipotesis. Terdapat pengaruh yang signifikan terhadap pelanggan PT. Media Televisi Indonesia (Metro TV). Hal ini dapat dilihat dari persamaan regresi linear sederhana yaitu $Y=7,680+0,390 x$, yang artinya bahwa perubahan $Y$ berjalan dua arah dengan perubahan $X$. Jadi setiap peningkatan nilai $X$ akan diikuti dengan penurunan nilai $Y$, begitu pula sebaliknya nilai $X$ menurun, maka nilai $Y$ akan meningkat. Jadi dapat disimpulkan bahwa Pengaruh Kualitas Pelayanan Terhadap Kepuasaan Pelanggan. Dan dari nilai koefisien korelasi yang ditemukan sebesar o,7oo sehingga dapat dikatakan kuat antara Kualitas pelayanan dan Kepuasan pelanggan pada PT. Metro TV, Koefisien determinasi lingkungan berpengaruh positif terhadap variabel kinerja sebesar 49,1\% sedangkan sisanya 50,9\% dipengaruhi oleh variabel lain yang tidak diketahui oleh peneliti. Dan nilai $t_{\text {hitung }}>t_{\text {tabel }}$, atau $(9,515>1.661)$ artinya terdapat pengaruh yang signifikan antara Pengaruh Kualitas Pelayanan Terhadap Kepuasan Pelanggan Pada PT. Media Televisi Indonesia (Metro TV).
\end{abstract}

Kata kunci: Kualitas Pelayanan; Kepuasaan Pelanggan.

\begin{abstract}
This study aims to determine how much the influence of service quality on customer satisfaction. And the company that is the object of this research is PT. Media Televisi Indonesia (Metro TV). The research method used is associative descriptive with a quantitative approach. The population in this study were customers at PT. Media Televisi Indonesia (Metro TV). By using unsaturated samples as many as 96 respondents. Data collection techniques by means of questionnaires, and data analysis techniques are validity test, reliability test, simple linear regression analysis, correlation coefficient analysis, coefficient of determination, and, hypothesis testing. There is a significant effect on customers of PT. Media Televisi Indonesia
\end{abstract}


kenapa menurunya jumlah klien yang ingin beriklan di stasiun Metro TV. Karena Metro TV Berfokus hanya pada acara Berita saja maka jumlah pelangan yang ingin memasang iklan di stasiun TV tersebut agak sedikit meragukan karena mereka takut jika mereka bekerjasama dengan Metro TV maka pemasukan mereka ikut menurun. Karena Adanya permasalahan diatas tentunya akan mempengaruhi kemajuan dan kualitas pelayanan.

Berdasarkan uraian diatas penulis tertarik melakukan penelitian untuk mengetahui seberapa besar 'Pengaruh Kualitas Pelayanan Terhadap Kepuasan Pelanggan Pada PT. Media Televisi Indonesia (METRO TV) “

\section{Perumusan Masalah}

Berdasarkan latar belakang masalah, maka penulis merumuskan masalah sebagai berikut :

1. Bagaimana kualitas pelayanan pada PT. Media Televisi Indonesia (Metro TV)?

2. Bagaimana kepuasan pelanggan pada PT. Media Televisi Indonesia (Metro TV)?

3. Bagaimana pengaruh kualitas pelayanan terhadap kepuasan pelanggan pada PT. Media Televisi Indonesia (Metro TV)?

\section{Tujuan Penelitian}

Sesuai dengan perumusan masalah di atas, maka penulis memberikan tujuan dan manfaat penelitian sebagai berikut:
1. Untuk mengetahui kualitas pelayanan pada PT. Media Televisi Indonesia (Metro TV).

2. Untuk mengetahui kepuasan pelanggan pada PT. Media Televisi Indonesia (Metro TV).

3. Untuk mengetahui pengaruh kualitas pelayanan terhadap kepuasan pelanggan pada PT. Media Televisi Indonesia (Metro TV)

\section{Kajian Literatur}

\section{Kualitas Pelayanan}

Kualitas Pelayanan sebuah kinerja yang dapat ditawarkan oleh seseorang kepada orang lain. Kinerja ini dapat berupa tindakan yang tidak berwujud serta tidak berakibat pada kepemilikan barang apapun dan terhadap siapapun, dan menurut Fitzsmmons bersaudara dalam Sulastiyono (2011 : 35-36) dalam bauran kualitas pelayanan terdapat indikator-indikator Antara lain:

a. Realiabilitas (Realiability)

Kemampuan untuk memberikan secara tepat dan benar jenis pelayanan yang telah dijanjikan kepada tamu.

b. Responsive (Responsiveness)

Kesadaran atau keinginan untuk cepat bertindak membantu tamu dan memberikan pelayanan yang tepat waktu.

c. Jaminan (Assurance)

Pengetahuan dan kesopansantunan serta kepercayaan diri para pegawai. Dimensi 
assurance memiliki ciri-ciri kompentesi untuk memberikan pelayanan, sopan dan memiliki sifat respek terhadap tamu.

\section{d. Empati (Empathy)}

Memberikan perhatian individu tamu secara khusus. Dimensi ini memiliki ciriciri: kemampuan untuk melakukan pendekatan, memberikan perlindungan, dan usaha untuk mengerti keinginan, kebutuhan dan perasaan tamu.

e. Nyata (Tangibles)

Sesuatu yang Nampak atau nyata, yaitu : penampilan para pegawai, dan fasilitasfasilitas pisik, lainnya seperti peralatan dan perlengkapan yang menunjang pelaksanaan pelayanan.

\section{Kepuasan Pelanggan}

Kepuasan Pelanggan merupakan produk dan layanan yang berkualitas berperan penting dalam membentuk kepuasan konsumen, selain itu erat kaitannya dalam menciptakan keuntungan bagi perusahaan. Menurut teori Winkle (2014:43) menyampaikan terdapat 3 sikap dalam kepuasan pelanggan. Indikator kepuasan pelanggan dapat dilihat dari :

a. Kongnitif (Keyakinan) adalah pengetahuan dan persepsi pelanggan yang di peroleh melalui pengalaman dengan suatu objek sikap dan informasi dari berbagai sumber pengetahuan dan persepsi ini biasanya berbentuk kepercayaan (believe) yaitu pelanggan mempercayai bahwa produk memiliki sejumlah atribut. Kognitif ini sering juga disebut sebagai pengetahuan dan kepercayaan pelanggan.

b. Afektif (Perasaan) menggambarkan emosi dan perasaan pelanggan menunjukkan penilaian langsung dan umum terhadap suatu produk, apakah produk itu disukai atau tidak disukai apakah produk itu baik atau buruk.

c. Konatif (Perilaku) menunjukkan tindakan seseorang atau kecenderungan perilaku terhadap suatu objek, kognatif berkaitan dengan tindakan atau perilaku yang akan dilakukan oleh pelanggan dan sering juga disebut sebagai intention.

Pada dasarnya kepuasan dan ketidakpuasan pelanggan atas produk/jasa akan berpengaruh pada pola perilaku selanjutnya. Hal ini ditunjukan pelanggan setelah proses pembelian. Apabila pelanggan merasa puas, maka dia akan menunjukan besarnya kemungkinan untuk membeli kembali produk yang sama. Pelanggan yang puas juga cenderung akan memberikan referensi yang baik terhadap produk/jasa kepada orang lain.

\section{Kerangka Pemikiran}




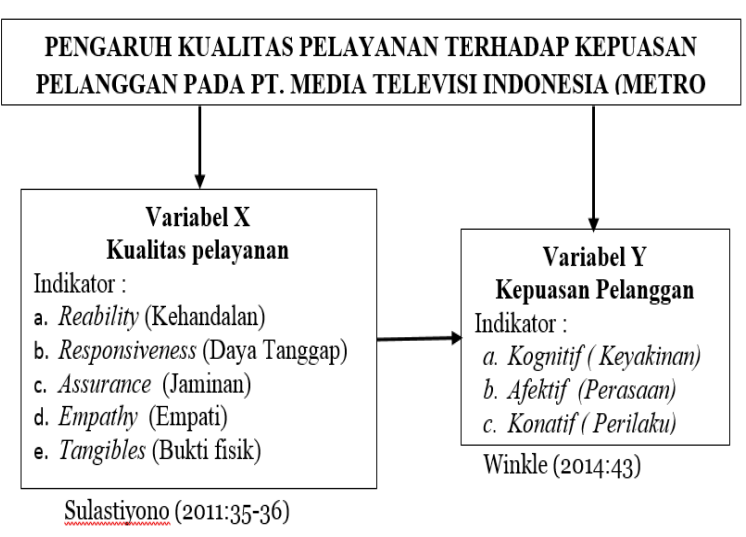

Gambar 1.1. Kerangka Pemikiran

\section{METODE}

Metode penelitian yang digunakan adalah bersifat daskriptif Assosiatif dengan pendekatan kuantitatif. Populasi dalam penelitian ini adalah pelanggan pada PT. Media Televisi Indonesia (Metro TV). Dengan menggunakan sampel tidak jenuh sebanyak 96 responden. Teknik pengumpulan data dengan cara kuesioner, dan teknik analisis data adalah uji validitas, uji reliabilitas, analisis regresi linear sederhana, analisis koefisien korelasi, koefisien determinasi, dan ,pengujian hipotesis.

\section{HASIL dan PEMBAHASAN}

\section{Hasil}

Uji Validitas Variabel Kualitas

\section{Pelayanan}

Tabel 1.2. Rangkuman Hasil Perhitungan Validitas Instrumen Variabel Kualitas Pelayanan

\begin{tabular}{|c|c|c|c|}
\hline $\begin{array}{c}\text { Butir } \\
\text { Pemyataan }\end{array}$ & rnitung & $r_{\text {tabel }}$ & Keterangan \\
\hline 1 & 0,654 & 0,168 & Valid \\
\hline 2 & 0,719 & 0,168 & Valid \\
\hline
\end{tabular}

\begin{tabular}{|c|c|c|c|}
\hline 3 & 0,720 & 0,168 & Valid \\
\hline 4 & 0,770 & 0,168 & Valid \\
\hline 5 & 0,745 & 0,168 & Valid \\
\hline 6 & 0,752 & 0,168 & Valid \\
\hline 7 & 0,765 & 0,168 & Valid \\
\hline 8 & 0,784 & 0,168 & Valid \\
\hline 9 & 0,805 & 0,168 & Valid \\
\hline 10 & 0,717 & 0,168 & Valid \\
\hline
\end{tabular}

Dari tabel rangkuman hasil perhitungan validitas instrumen pada variabel Kualitas pelayanan (X) diatas dapat dilihat pada 10 butir pernyataan yang dijadikan sebagai instrumen pada variabel Kualitas pelayanan (X) dapat dikatakan valid. karena nilai rhitung dari masing-masing pernyataan lebih besar dari pada nilai rtabel dengan tingkat alfa (taraf kesalahan) $=10 \%$. nilai rtabel sebesar 0,168.

\section{Uji Validitas Variabel Kepuasan} Pelanggan

Tabel 1.3. Rangkuman Hasil Perhitungan
Validitas Instrumen Variabel Kepuasan
Pelanggan (Y)
\begin{tabular}{|c|c|c|c|}
\hline $\begin{array}{c}\text { Butir } \\
\text { Pernyataan }\end{array}$ & rhitung & rtabel & Keterangan \\
\hline 1 & 0,686 & 0,168 & Valid \\
\hline 2 & 0,819 & 0,168 & Valid \\
\hline 3 & 0,811 & 0,168 & Valid \\
\hline 4 & 0,768 & 0,168 & Valid \\
\hline 5 & 0,804 & 0,168 & Valid \\
\hline 6 & 0,812 & 0,168 & Valid \\
\hline
\end{tabular}

Dari tabel rangkuman hasil perhitungan validitas instrumen pada variabel Kepuasan Pelanggan (Y) diatas dapat dilihat pada 6 butir pernyataan yang dijadikan sebagai instrumen pada variabel Kepuasan 
Pelanggan (Y) dapat dikatakan valid karena nilai $\mathrm{r}_{\text {hitung }}$ dari masing-masing pertanyaan lebih besar dari pada nilai $r_{\text {tabel }}$ dengan tingkat alfa ( taraf kesalahan ) $=10 \%$. nilai $\mathrm{r}_{\text {tabel }}$ sebesar 0,168.

\section{Uji Reliabilitas}

Tabel 1.4. Hasil Uji Reliablitas Kualitas
Pelayanan dan Kepuasan Pelanggan
\begin{tabular}{|c|l|c|c|l|}
\hline No & Variabel & rhitung & rtabel & Keterangan \\
\hline 1 & $\begin{array}{l}\text { Kualitas } \\
\text { Pelayanan }\end{array}$ & 0,906 & 0,6 & Reliabel \\
\hline 2 & $\begin{array}{l}\text { Kepuasan } \\
\text { Pelanggan }\end{array}$ & 0,873 & 0,6 & Reliabel \\
\hline
\end{tabular}

\section{Analisis Data Statistik Deskriptif}

Analisis data statitistik deskriptif

berpedoman pada rentang skala tabel berikut:

\section{Tabel 1.5. Analisis Rentang Skala}

\begin{tabular}{|l|c|l|c|c|}
\hline Kriteria & Disingkat & Kriteria & Disingkat & $\begin{array}{c}\text { Skor } \\
\text { Nilai }\end{array}$ \\
\hline $\begin{array}{l}\text { Sangat } \\
\text { Setuju }\end{array}$ & SS & $\begin{array}{l}\text { Sangat } \\
\text { baik }\end{array}$ & SB & $\begin{array}{l}4,20- \\
5,00\end{array}$ \\
\hline Setuju & S & Baik & B & $3,40-4,19$ \\
\hline $\begin{array}{l}\text { Ragu- } \\
\text { ragu }\end{array}$ & RR & $\begin{array}{l}\text { Ragu- } \\
\text { ragu }\end{array}$ & CB & $1,60-3,39$ \\
\hline $\begin{array}{l}\text { Tidak } \\
\text { Setju }\end{array}$ & TS & $\begin{array}{l}\text { Tidak } \\
\text { Baik }\end{array}$ & TB & $1,80-2,59$ \\
\hline $\begin{array}{l}\text { Sangat } \\
\text { Tidak } \\
\text { Setuju }\end{array}$ & STS & $\begin{array}{l}\text { Sangat } \\
\text { Tidak } \\
\text { Baik }\end{array}$ & STB & $1,00-1,79$ \\
\hline
\end{tabular}

\section{Analisa Deskriptif Variabel}

\section{Kualitas Pelayanan (X)}

Tabel 1.6. Distribusi Jawaban Responden Terhadap Variabel Kualitas Pelayanan

\begin{tabular}{|c|c|c|c|c|c|c|c|c|c|}
\hline \multirow[t]{2}{*}{ No } & \multirow{2}{*}{$\begin{array}{l}\text { Perta- } \\
\text { nyaan }\end{array}$} & \multicolumn{5}{|c|}{ Jawaban } & \multirow[t]{2}{*}{ Total } & \multirow[t]{2}{*}{ Skor } & \multirow[t]{2}{*}{$\begin{array}{l}\text { Rata- } \\
\text { Rata }\end{array}$} \\
\hline & & SS & $\mathrm{S}$ & $\mathrm{R}$ & TS & STS & & & \\
\hline \multicolumn{10}{|c|}{ Bukti Fisik (Tangibles) } \\
\hline 1 & Inst_1 & 14 & 61 & 17 & 4 & 0 & 96 & 373 & 3,84 \\
\hline 2 & Inst_2 & 12 & 51 & 27 & 5 & 1 & 96 & 356 & 3,67 \\
\hline \multicolumn{10}{|c|}{ Kehandalan (Reability) } \\
\hline 3. & Inst_3 & 14 & 53 & 23 & 5 & 1 & 96 & 362 & 3,73 \\
\hline 4. & Inst_4 & 8 & 42 & 35 & 9 & 2 & 96 & 333 & 3,43 \\
\hline \multicolumn{10}{|c|}{ Daya tanggap (Responsiveness) } \\
\hline 5. & Inst_5 & 11 & 45 & 37 & 2 & 1 & 96 & 351 & 3,61 \\
\hline 6. & Inst_6 & 14 & 39 & 34 & 6 & 3 & 96 & 343 & 3,53 \\
\hline
\end{tabular}

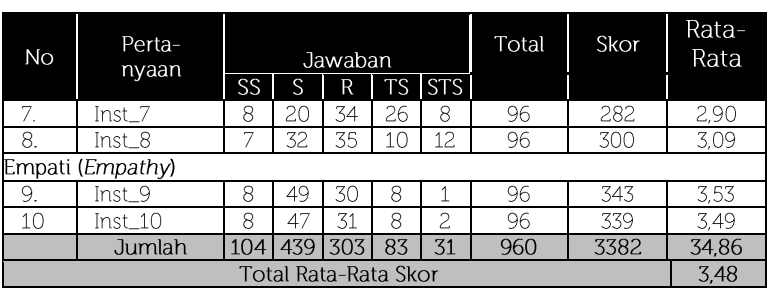

Dari perhitungan di atas diperoleh rata-rata skor 3,48 karena berada diantara interval 3,40-4,19, maka penilaian pelanggan kualitas pelayanan yang diberikan tergolong baik. Dengan indikator kualitas layanan tertinggi pada bukti fisik (tangibles), sedangkan indikator terendahnya pada jaminan (insurance)

\section{Analisa Diskriptif Variabel} Kepuasan Pelanggan (Y)

Tabel 1.7. Distribusi Jawaban Responden Terhadap Variabel Kepuasan Pelanggan

\begin{tabular}{|c|c|c|c|c|c|c|c|c|c|}
\hline \multirow{2}{*}{$\begin{array}{l}N \\
\mathrm{O}\end{array}$} & \multirow{2}{*}{$\begin{array}{l}\text { Perta } \\
\text { nyaan }\end{array}$} & \multicolumn{5}{|c|}{ Jawaban } & \multirow[b]{2}{*}{ Total } & \multirow[b]{2}{*}{ Skor } & \multirow{2}{*}{$\begin{array}{l}\text { Rata- } \\
\text { Rata }\end{array}$} \\
\hline & & SS & $S$ & $\mathrm{R}$ & TS & STS & & & \\
\hline \multicolumn{10}{|c|}{ Kognitif (Keyakinan) } \\
\hline 1 & Inst__ & 7 & 68 & 17 & 4 & 0 & 96 & 366 & 3,77 \\
\hline 2 & Inst_ & 5 & 59 & 25 & 5 & 2 & 96 & 348 & 3,58 \\
\hline \multicolumn{10}{|c|}{ Afektif (Perasaan) } \\
\hline 3 & Inst_ & 4 & 60 & 25 & 5 & 2 & 96 & 347 & 3,57 \\
\hline 4 & Inst_ & 3 & 43 & 37 & 10 & 3 & 96 & 321 & 3,30 \\
\hline \multicolumn{10}{|c|}{ Konatif (Perilaku) } \\
\hline 5 & Inst_ & 6 & 48 & 38 & 2 & 2 & 96 & 342 & 3,52 \\
\hline 6 & Inst_ & 7 & 44 & 35 & 6 & 4 & 96 & 332 & 3,42 \\
\hline & Jumlah & 32 & 322 & 177 & 32 & 13 & 576 & 2056 & 21,19 \\
\hline \multicolumn{9}{|c|}{ Total Rata-Rata Skor } & 3,53 \\
\hline
\end{tabular}

Dari perhitungan di atas diperoleh rata-rata skor 3,53 karena berada diantara interval 3,40-4,19, maka penilaian pelanggan kepuasan pelanggan yang tergolong baik. Dengan indikator tertinggi pada kognitif (keyakinan), sedangkan indikator terendahnya pada indikator afektif (perasaan). 


\section{Analisis Data Statistik Inferensial}

\section{Uji Regresi Linier Sederhana}

Dalam penelitian analisis regresi bertujuan untuk mengetahui seberapa besar pengaruh Kualitas Pelayanan terhadap Kualitas Pelayanan pada PT. Media Televisi Indonesia (Metro TV). Hasil perhitungan data diperoleh:

$$
\begin{array}{ll}
\mathrm{n} & =96 \\
\sum \mathrm{X} & =3382 \\
\sum \mathrm{Y} & =2056 \\
\sum \mathrm{X}^{2} & =123112 \\
\sum \mathrm{XY} & =73978
\end{array}
$$

Perhitungan konstanta regresi (a)

$$
\begin{gathered}
a=\frac{\left(\sum y\right)\left(\sum x^{2}\right)-\left(\sum x\right)\left(\sum x y\right)}{n\left(\sum x^{2}\right)-\left(\sum x\right)^{2}} \\
a=\frac{\left(\sum y\right)\left(\sum x^{2}\right)-\left(\sum x\right)\left(\sum x y\right)}{n\left(\sum x^{2}\right)-\left(\sum x\right)^{2}} \\
a=\frac{(2056)(123112)-(3382)(73978)}{96(123112)-(3382)^{2}} \\
a=\frac{(253118272)-(250193596)}{(11818752)-(11437924)} \\
a=\frac{(2924676)}{(380828)} \\
a=7.680
\end{gathered}
$$

Perhitungan koefisien regresi (b)

$$
\begin{aligned}
& b=\frac{n\left(\sum x y\right)-\left(\sum x\right)\left(\sum y\right)}{n\left(\sum x^{2}\right)-\left(\sum x\right)^{2}} \\
& b=\frac{96(73978)-(3382)(2056)}{96(123112)-(3382)^{2}} \\
& b=\frac{(7101888)-(6953392)}{(11818752)-(11437924)}
\end{aligned}
$$

$$
b=\frac{(148496)}{(380828)}
$$$$
b=0,390
$$

Dari perhitungan diperoleh persamaan $\mathrm{Y}=$ $7,680+0,390 X$, interprestasinya adalah konstanta sebesar 7,680 menyatakan bahwa jika variabel kualitas pelayanan bernilai nol, maka 7,680 kepuasan pelanggan satuan. Jika X dinaikkan 1 satuan maka akan meyebabkan kenaikkan sebesar 0,390 satuan pada kepuasan pelanggan.

\section{Uji Korelasi Product Moment}

Hasil perhitungan data diperoleh:

$$
\begin{array}{ll}
\mathrm{n} & =96 \\
\sum \mathrm{xi} & =3382 \\
\sum \mathrm{y} & =2056 \\
\sum \mathrm{x}^{2} & =123112 \\
\sum \mathrm{y}^{2} & =45262 \\
\sum \mathrm{xy} & =73978
\end{array}
$$

Sehingga koefisien korelasinya

$$
\begin{aligned}
& R_{x y}=\frac{n(\Sigma \mathrm{xy})-(\mathrm{xxi})(\mathrm{\Sigma y})}{\sqrt{\left\{n\left(\Sigma \mathrm{x}^{2}\right)-(\Sigma \mathrm{xi})^{2}\right\}\left\{n\left(\Sigma \mathrm{y}^{2}\right)-(\Sigma \mathrm{y})^{2}\right\}}} \\
& R_{x y}=\frac{96(73978)-(3382)(2056)}{\sqrt{\left\{96(123112)-(3382)^{2}\right\}\left\{96(45262)-(2056)^{2}\right\}}} \\
& R_{x y}=\frac{7101888-6953392}{\sqrt{(11818752-11437924)(4345152-4227136)}} \\
& R_{x y}=\frac{148496}{\sqrt{(380828)(118016)}} \\
& R_{x y}=\frac{148496}{\sqrt{44943797248}} \\
& R_{x y}=\frac{148496}{211999,5} \\
& R_{x y}=0,700
\end{aligned}
$$




Tabel 1.8. Pedoman Untuk Memberikan
Interprestasi Koefisien Korelasi
\begin{tabular}{|c|l|}
\hline Interval Koefisien & Tingkat Hubungan \\
\hline $0,00-0,199$ & Sangat Rendah \\
\hline $0,20-0,399$ & Rendah \\
\hline $0,40-0,599$ & Sedang \\
\hline $0,60-0,799$ & Kuat \\
\hline $0,80-1,000$ & Sangat Kuat \\
\hline
\end{tabular}

Sumber : Sugiyono (2014:184)

Hasil perhitungan, nilai koefisien korelasi $\mathrm{r}_{\mathrm{xy}}$ sebesar 0,700. Karena koefisien korelasi berada di antara 0,060-0,799, maka kualitas pelayanan dan kepuasan pelanggan pada PT. Media Televisi Indonesia (Metro TV) memiliki tingkat hubungan yang kuat (Sugiyono:2014, h.184).

\section{Uji Koefisien Determinasi}

Untuk mengetahui seberapa besar kontribusi Kualitas pelayanan (X) terhadap variabel kepuasan pelanggan (Y) digunakan perhitungan koefisien determinasi sebagai berikut :

$$
\begin{aligned}
\mathrm{KD} & =r^{2} \times 100 \% \\
& =(0,700)^{2} \times 100 \% \\
& =0,491 \times 100 \% \\
& =49,1 \%
\end{aligned}
$$

Berdasarkan perhitungan nilai 49,1\%. Hal ini menunjukkan bahwa kontribusi pengaruh kualitas pelayanan terhadap kepuasan pelanggan pada PT. Media Televisi Indonesia (Metro TV) yakni 49,1\%. Sedangkan sisanya $(100 \%-49,1 \%)=50,9 \%$ kepuasan pelanggan pada PT. Media Televisi Indonesia (Metro TV) dipengaruhi variabel lain yang tidak diteliti.

\section{Uji Hipotesis}

Hipotesis yang akan diuji:

Ho : $p=0$ : Tidak terdapat pengaruh antara Kualitas Pelayanan terhadap Kepuasan Pelanggan pada PT. Media Televisi Indonesia (Metro TV).

Ha : $p \neq 0$ :Terdapat pengaruh antara Kualitas Pelayanan terhadap Kepuasan Pelanggan pada PT. Media Televisi Indonesia (Metro TV).

Uji Signifikan untuk data $\mathrm{n}=96$ dan nilai $\mathrm{rxy}$ = 0,700 maka nilai:

$$
\begin{aligned}
& t=\frac{r \sqrt{n-2}}{\sqrt{1-r^{2}}} \\
& t=\frac{0,700 \sqrt{96-2}}{\sqrt{1-(0,700)^{2}}} \\
& t=\frac{0,700 \sqrt{94}}{\sqrt{1-0,732}} \\
& t=\frac{6,7867}{0,509} \\
& t=9,515
\end{aligned}
$$

Sedangkan nilai $\mathrm{t}$ tabel untuk $\mathrm{n}=96$; $\mathrm{dk}=\mathrm{n}$ $2=96-2=94$ dengan tingkat signifikan nilai p-value $10 \%$ diperoleh nilai $t_{\text {tabel }}=1,661$. Karena nilai $t_{\text {hitung }}(9,515)>t_{\text {tabel }}(1,661)$ maka Ho ditolah dan $\mathrm{Ha}$ diterima. Sehingga disimpulkan kualitas pelayanan berpengaruh signifikan terhadap kepuasan pelanggan pada PT. Media Televisi Indonesia (Metro TV).

\section{Pembahasan}


1. Kualitas pelayanan pada PT. Media Televisi Indonesia (Metro TV) tergolong baik, dengan nilai rata-rata skor jawaban responden 3,48 dan berada diantara interval 3,40-4,19. Indikator kualitas layanan yang harus dipertahankan yaitu dalam hal bukti fisik (tangible), sedangkan indikator yang perlu ditingkatkan yaitu pada jaminan (insurance) yang diberikan.

2. Kepuasan pelanggan terhadap PT. Media Televisi Indonesia (Metro TV) tergolong baik, dengan nilai rata-rata skor jawaban responden 3,53 dan berada diantara interval 3,40-4,19. Indikator yang harus dipertahankan yaitu kognitif (keyakinan), sedangkan indikator yang harus ditingkatkan pada indikator afektif (perasaan).

3. Kualitas layanan berpengaruh terhadap kepuasan pelanggan pada PT. Media Televisi Indonesia (Metro TV), hal ini diperkuat dengan persamaan $\mathrm{Y}=7,680+$ o,390X dan hasil uji $\mathrm{t}$ diperoleh $\mathrm{t}_{\text {hitung }}$ $(9,515)>t_{\text {tabel }}(1,661)$. Adapun konstribusi kualitas layanan terhadap kepuasan pelanggan sebesar 49,1\%, sisanya sebesar 50,95 ditentukan oleh variabel lain yang tidak diteliti.

\section{SIMPULAN}

\section{Kesimpulan}

1. Kualitas pelayanan pada PT. Media Televisi Indonesia (Metro TV) mendapatkan hasil baik dengan nilai ratarata skor jawaban responden 3,48 dan berada diantara interval 3,40-4,19. Indikator kualitas layanan yang harus dipertahankan yaitu bukti fisik (tangible).

2. Kepuasan Pelanggan pada PT Media Televisi Indonesia (Metro TV) mendapatkan hasil baik. dengan nilai rata-rata skor jawaban responden 3,53 dan berada diantara interval 3,40-4,19. Indikator kepuasan yang harus dipertahankan yaitu kognitif (keyakinan) pelanggan.

3. Hasil Uji $\mathrm{t}$ diperoleh bahwa kualitas pelayanan berpengaruh terhadap kepuasan pelanggan pada PT. Media Televisi Indonesia (Metro TV) dengan kontribusi sebesar 49,1\%. Diperkuat dengan persamaan $\mathrm{Y}=7,680+0,390 \mathrm{X}$ dan hasil uji $t$ diperoleh $t_{\text {hitung }}(9,515)>$ $t_{\text {tabel}}(1,661)$.dengan.

\section{Saran}

1. PT. Media Televisi Indonesia (Metro TV) agar dapat meningkatkan kualitas layanan terhadap pelanggan khususnya dalam hal jaminan (insurance) yang diberikan.

2. Dalam hal kepuasan pelanggan, PT. Media Televisi Indonesia (Metro TV) agar meningkatkan kepuasan pelanggan dalam hal afektif (perasaan).

3. Perlu adanya penelitian lanjutan untuk meneliti variabel-variabel lainnya yang 
mempengaruhi kualitas pelayanan dan kepuasan pelanggan.

\section{DAFTAR PUSTAKA}

Arifin, Imamul dan Giana Hadi W, 2007."Membuka Cakrawala Ekonomi”. PT. Setia Purna, Jakart.

Assauri, Sofjan. 2004. Manajemen Pemasaran. Jakarta: Rajawali Press. , 2014. "Manajemen Pemasaran". Raja Grafindo Persada: Jakarta.

Becherel, Lionel Vellas Francois. 2018. "Pemasaran Pariwisata Internasional”. Yayasan Obor Indonesia. Jakarta.

Dharmemesta dan Handoko, 2011, Manajemen Pemasara: Analisis Perilaku Konsumen, BPFE, Yogyakarta.

Ghozali, Imam, 2006."Aplikasi Analisis Multivariate Dengan SPSS". Cetakan keempat. Badan penerbit Universitas Diponegoro, Semarang.

Handoko, 2012, Manajemen Personalia dan

Sumber Daya Manusia, Penerbit, BPFE, Yogyakarta.

Hasibuan, Melayu S.P. 2009. Manajemen: Dasar,Pengertian, dan MasalahEdisi Revisi.Jakarta : Bumi Aksara. , 2014, Manajemen Sumber Daya Manusia, Edisi Revisi, PT. Bumi Aksara, Jakarta.
Husein Umar. "Metode Penelitian untuk Skripsi dan Tesis Bisnis”. PT Raja Grafindo Persada, Jakarta, 2008.

Istijanto, 2009. "Aplikasi Praktis Riset Pemasaran”, Gramedia Pustaka Utama, Jakarta.

Kotler, Philip. 2002. Marketing Management. New Jersey: The Millennium Edition, PrenticeHall International Edition. , 2009. "Manajemen Pemasaran", Edisi 13. Erlangga. Jakarta. 2012. "Manajemen Pemasaran Perspektif Asia”, Buku Dua, Edisi Pertama, Andy, Yogyakarta.

Kotler And Amstrong. 2008 Principles of Marketing. Prentice Hall: Person Education, Inc 2009, Prinsip-prinsip Pemasaran Edisi. 13 Jilid 1, PT Indeks Jakarta.

2012. "Prinsip-prinsip

Pemasaran”, Edisi13. Jilid1. Erlangga. Jakarta.

Kotler, Philip dan Kevin Lane Keller, 2008. Manajemen Pemasaran, Jilid 1, Penerbit Erlangga. Jakarta. , 2009. "Manajemen Pemasaran", Jilid 1, edisi Ketiga Belas, Terjemahan Bob Sabran, MM, Penerbit Erlangga, Jakarta. . 2009. Marketing Manajement. 14th ed. New Jersey: Prentice Hall. 

. 2009. Alih Bahasa : Benyamin

Molan Manajement Pemasaran. Edisi

Ketigabelas. Jilid 1 dan 2. Cetakan

Keempat. PT. Indeks. Jakarta.

Lupiyoadi, 2011, Manajemen Pemasaran,

Rajawali Press, Jakarta.

Lupiyoadi, Rahmat, dan A. Hamdani, 2006,

Manajemen Pemasaran Jasa,

Salemba Empat, Jakarta.

Malhotra, N.K., "Riset Pemasaran", Edisi

keempat, Jilid 1, PT Indeks, Jakarta, 2009.

Ma'ruf, Hendri. 2005. Pemasaran Ritel. Jakarta: Gramedia Pustaka Utama.

Mowen and Miror, 2005, Perilaku Konsumen, Erlangga, Jakarta.

Robbins and Coulter, 2013, Manajemen, Penerbit Erlangga, Jakarta.

Raharjani, Jeni. 2005. Analisis Faktor-faktor yang Mempengaruhi Keputusan Pemilihan Pasar Swalayan Sebagai Tempat Berbelanja. Dalam Jurnal Studi Manajemen \& Organisasi, Vol. 2 No. 1 Hal 1-15

Rangkuti, Freddy. 2009. "Strategi Promosi yang Kreatif”, Gramedia. Pustaka Utama. Jakarta.

Safroni, Ladzi. 2012. Manajemen dan Reformasi Pelayanan Publik dalam Konteks Birokrasi Indonesia. Surabaya: Aditya Media Publishing.
Schiffman \& Kanuk, 2007, Perilaku Konsumen, dialihbahasakan oleh Zulkifli Kasip.

Sugiyono, 2013 Metode Penelitian

Pendidikan Pendekatan Kuantitatif, Kualitatif, dan R\&D. Bandung:

Alfabeta. 